\title{
The Legal Value of Secret Informing in The Iraqi Law
}

\author{
Dr. Khalied Mohammad Ajij \\ Department of Law/ College of Law/Cihan University/ Sulaimanya
}

\begin{abstract}
The subject of the secret detective in the Iraqi legislation is one of the most vital topics, which has a great interest in jurisprudence and legislation as it is subject to a fundamental and important idea that is supposed to be based on the entire judicial process. This idea is based on neutrality, as well as specialization and determining the jurisdiction of the judiciary. The current study deals with illustrating what secret informing is, its justifications and the kinds of the secret detectives. The paper reveals that getting the aid of the secret detective is an important way in helping the authorities in the process of investigations and trailing. The paper shows clearly that the secret detectives should be committed legally and that any abuse of such information will result into violating human rights. theory To the secret informer and his choice under conditions no less important in the choice of judge for a task entrusted to him to achieve justice and non-oppression of the people of our society.
\end{abstract}

\section{INTRODUCTION}

In criminal litigation, and in the promotion of guarantees of justice towards the rights and freedoms of individuals. The impartiality of the judicial process and the procedures to be followed in the direction of the secret informant and the accused, and seriously contributes to the issuance of judgments from a neutral judiciary in which rights and freedoms are exercised with sufficient guarantees, and the assignment of the secret detective to the indictment function ensures a balance between the rights of the acc used on the one hand and the preservation of the right of society on the other. The positive of the judicial process is intertwined with the role of the judge in the criminal case, from which the search for evidence is collected and collected at the pre-trial stage and then its weight and weight at trial which should be studied analytically, and the extent of its scope, and highlight its role in determining the proper functioning of criminal justice in terms of the functions of indictment and investigation.

\section{DEFINITION OF SECRET DETECTIVE}

The most recognized definition of the secret detective is "Any individual who provides useful and credible information to JLEA regarding felonious criminal activities, and form whom the JLEA expects intends to obtain additional useful and credible information regarding such activities in the future". (Fitzgerald, 2007, p.293). Another definition is that the detective secret "A confidential informant is a person who provides information to a police officer about suspected criminal activity"(Fredrickson et. al., 2004, p. 129)

So, it can be stated that the secret detective can be defined as the person who makes the declaration before the judicial authorities, whether this statement is oral or written, which is intended to inform the media of a criminal offense and their loyalty, after which the perpetrator has been appointed in the news or has not been appointed(Nasrawi, 1974).It is also known as "any interested person who submits to the investigating judge specific crimes under the law that have occurred or will occur, requesting anonymity and not being considered witnesses (Ibrahim, 2012, p. 129).

\section{THE MOTIVES OF INFORMING}

The knowledge of the motive that led the informant to provide $t$ information should be taken care of by the members of the judicial control. It is worth mentioning that the success and effectiveness of the investigation depends on the effectiveness and seriousness of the news provided by the secret detective in exchange for or without any consideration or no other reason for the criminal and his activities( Gad, 2001).

"Informants usually fall into specific categories depending on their motives. Many informants are working off charges in the court system, or doing it to receive money. Many are doing it for personal reasons such as to eliminate drugs and crime in their neighborhood, or they may have had a family member or close friend become involved with illicit drugs. Often there is more than one motivating factor.". And he also said in page (133) that: 
"informants who are working for pay, or reduce or eliminate criminal charges against them have personal or secondary motives". (Fredrickson, 2004, p. 132).

\section{THEKINDS AND THE FEATURES OF THE SECRET DECEIVES}

The jurisprudence differ in the kinds of the kinds of secret detectives as inthe following: "There are essentially two types of informants: those who were merely observers criminal events and those informants may have been materially involved in the crime to the point at which they may have to be witnesses in criminal trials". (Ingram,2012, p.388). Other jurisprudents state that there are three kinds of detectives

1. Anonymous Informant.

2. Confidential Informant.

3. Past Proven ReliableConfidential Informant

(Fredrickson, 2004).

As far as the features are concerned, some jurisprudents state the following as the main features that the deceives should enjoy:

1. Intelligence.

2. Absence of delusions and other signs of irrational thinking.

3. Absence of "nervousness" or psychoneurotic manifestations.

4. Unreliability

\section{THE LEGAL VALUE OF SECRET INFORMANTS IN THE IRAQI LAW.}

In fact, the Iraqi legislature did not determine a specific means of informing which might be orally, written or any other means. This is to be seen according article 47 of the Iraqi Criminal Procedure Code. Indeed, there is nothing that is called a secret informant in the Iraqi law but this is so called as it is used in the Iraqi society. The real naming of the secret informant according to the aforementioned code is the informant who asks not to be identified or to be a witness. His statements are to be taken in specialregistration of the informants and in the criminal cases. This section clarifies the stand of the Iraqi law concerning the importance ofthe secret informant in the process of investigation and also the trail.The Iraqi law stated in the Criminal Procedure Code No. (23) of 1971 that it is the law that regulates all proceedings before the criminal courts from the informing until the ruling of the judge is issued. In other words, although this law did not expressly state in its articles an explicit provision governing the treatment of confidential informing at the investigative stage, Article (47/2) of the Iraqi Rules of Procedure authorized the informant of crimes that are harmful to the internal and external security of the state and crimes punishable by death or life imprisonment As a witness to the fact that the judge shall conduct the investigation procedures in accordance with the rules, taking advantage of the information contained in the informing provided that such information should be enhanced by physical evidences, otherwise, it is not possible to take the sayings of the secret informant in the process of investigation. It is clear from this text that there is a difference between the role of testimony and the role of the secret informant in several legal subjects. Therefore, the sayings of the secret informant cannot be

considered as a powerful argument but as an inference or a reversible hypothesis(Al-Qaisi, 2012).

On the other hand, the legal value of the secret informant is represented in the process of trailing. The statements of the secret informant in Iraq can be taken in the form of inference. It is not permissible to rule on the case before the courts unless these statements or evidence are based on material evidence or evidence. It is not possible to build the judgment but to take it as an inference. Whether it was in the initial investigation or trial stage, and thus the secret informer is released from the scope of the rule that governs the informants, which requires that the statements of the laboratory be recorded and signed, such as Articles 49 and 58 of the Code of Criminal Procedure.

\section{CONCLUSION}

It is possible to state that the secret informant according to the Iraqi legislation can be considered an important source in the processes of investigation and trail. However, the statements of the secret informant should be based on physical and material evidences. If they are not, it is not possible to consider such statements in the conviction of the accused. It is clear that the secret informant doesn't swear legally. His statement is considered as the witness of someone who is under fifteen and this is considered in the Iraqi law as a statement of inference and which is heard as an inference statement. However, the information of the secret detective should be considered carefully and not to hasten the decision upon such information because not all information given are true.

References: 


\section{Bibliography}

[1] Al Qaisi, Abdul Qadir Mohammed (2012). Detective and secret source between the detection of crime and false news, Sabah SabahSadeq Al - Anbari, Baghdad, 2009.

[2] Fitzgerald, Dennis, G. (2004) Informants and Undercover Investigations: A Practical Guide to Law. USA: Policy CRC Press, Taylor \& Francis Group.

[3] Fredrickson, Darin D. \& RAYMOND P. SILJANDER (2004). Street Drug Investigation: A Practical Guide for Plainclothes and Uniformed Personnel, CHARLES C THOMAS PUBLISHER, LTD. Springfield Illinois, U.S.A.

[4] Ibrahim, Esmaeel, S. (2012). The Legal Value of the statement of the Detective Informant. Baghdad.

[5] Ingram, Jefferson L. (2012). Criminal Evidence, Eleventh Edition, U.S.A: Anderson Publishing.

[6] Gad, Nabil, A. (2001). Foundations of Criminal Investigation and Practical Research. Cairo: Police College Press.

[7] Madinger, John (1999). Confidential Informant: Law Enforcement's Most Valuable Tool, Library of CRC Press LLC, U.S.A.

[8] Nasrawi, Sami. (1974). A Study in the Foundations of Criminal Trials, C1, Baghdad. 